"Corporate social responsibility of a multinational bank and its South African subsidiary"

\begin{tabular}{ll} 
AUTHORS & $\begin{array}{l}\text { Amanda Koffman-Xaba } \\
\text { Geoff A. Goldman }\end{array}$ \\
\hline ARTICLE INFO & $\begin{array}{l}\text { Amanda Koffman-Xaba and Geoff A. Goldman (2016). Corporate social } \\
\text { responsibility of a multinational bank and its South African subsidiary. Banks and } \\
\text { Bank Systems, 11(1), 23-33. doi:10.21511/bbs.11(1).2016.03 }\end{array}$ \\
\hline DOI & http://dx.doi.org/10.21511/bbs.11(1).2016.03 \\
\hline RELEASED ON & Monday, 25 April 2016 \\
\hline JOURNAL & "Banks and Bank Systems" \\
\hline FOUNDER & LLC "Consulting Publishing Company "Business Perspectives"
\end{tabular}

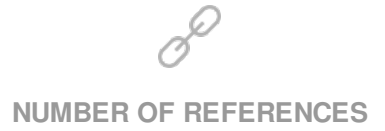

0

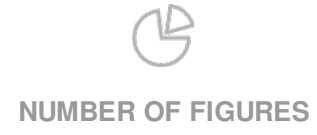

0

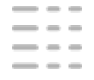

NUMBER OF TABLES

0

(C) The author(s) 2022. This publication is an open access article. 
Amanda Koffman-Xaba (South Africa), Geoff A. Goldman (South Africa)

\title{
Corporate social responsibility of a multinational bank and its South African subsidiary
}

\begin{abstract}
Africa has become increasingly attractive to foreign investors, but the establishment of operations in emerging markets poses challenges for multinationals. One such challenge is implementing of corporate social responsibility (CSR) effectively across all subsidiaries. This study aims to determine whether there are differences in CSR expectations and praxis between a multinational bank and its subsidiary operating in South Africa. Through qualitative research methods, a case study research design approach was utilized to study CSR activities in the parent company and CSR activities in its South African subsidiary. Data collected from ten interviews are analyzed using open, axial and selective coding procedures. The study concludes that there are nuanced gaps in CSR expectations, and between the parent company and its South African subsidiary. Global CSR strategies may be applied consistently across subsidiaries, but they do not necessarily address core issues faced in emerging economies, placing doubts upon the practicality of these efforts.
\end{abstract}

Keywords: corporate social responsibility, multinationals, South African subsidiary.

JEL Classification: F23, G21, G34, M14.

\section{Introduction}

Africa has experienced a $27 \%$ increase in foreign direct investment by developed nations between 2010 and 2011 due, in part, to a growing consumer base (Ernst \& Young, 2012). Thus, many South African based organizations have been targeted for mergers and acquisitions by multinational organizations. This research focuses on one such example, which occurred in 2005 when $56 \%$ of a leading South African bank was acquired by a multinational bank with its head office in the $\mathrm{UK}^{1}$.

When multinational organizations invest in emerging economies, strategies need to be different in approach to those followed in developed economies, as they need to be cognisant of the complexities faced by business in emerging economies (Peters, Miller \& Kusyk, 2011). Multinational organizations, therefore, need to approach corporate strategies (such as corporate social responsibility, or CSR) in a collaborative manner which involves local stakeholders and local context (Tobey \& Perera, 2012). When, specifically, looking at CSR, multinational organizations often find themselves caught between which CSR initiatives they should contribute toward in the host country and the CSR program in place in their home countries (Kolk \& Lenfant, 2010). In South Africa, defining and implementing CSR requires organizations to comprehend "the extremely uneven distribution of resources between blacks and whites institutionalized as part of the apartheid system" (Lund-Thompson, 2005, p. 624). There is a strong focus on transformation in

(c) Amanda Koffman-Xaba, Geoff A. Goldman, 2016.

Amanda Koffman-Xaba, Masters' student, Department of Business Management, University of Johannesburg, South Africa.

Geoff A. Goldman, Associate Professor, Department of Business Management, University of Johannesburg, South Africa.

${ }^{1}$ The bank wishes to remain anonymous, as explained in the methodology section of this paper.
South African organizations' CSR, resultant from domestic pressures (Baskin, 2006) emanating from the country's apartheid legacy.

\section{Literature review}

An extensive body of knowledge exists concerning CSR and its various derivatives such as corporate social investment, corporate citizenship and corporate sustainability (Carroll \& Shabana, 2010). This literature review will not attempt to define CSR or map its evolution. Rather, it will focus on how CSR initiatives are adopted by multinational organizations and how CSR is interpreted and implemented in emerging economies.

Any discussion concerning CSR needs acknowledging the notion that CSR is a concept with its proponents and detractors. Fundamentally, CSR is an ethical conception which has become standard in business organizations, and is now the norm rather than the exception (Vurro \& Perrini, 2011; Carroll \& Shabana, 2010; Sharma \& Talwar, 2005). Despite the ongoing debate around what CSR means and what it involves, organizations are expected to have a certain level of responsibility towards society that involves more than just being profitable (Carroll \& Shabana, 2010). Bell (cited in Nehme \& Wee, 2008, p. 130) states on the matter:

"...to think of the business corporation simply as an economic instrument is to fail totally to understand the meaning of social changes of the last half century."

Essentially, CSR is embedded in stakeholder theory which posits that an organization should not use organizational resources for the sole purpose of profit maximization and owners' return on investment, but should ensure that resources benefit all stakeholders (Freeman, 1984). Thus, organizations have an obli- 
gation to evaluate the impact its business activities have on all stakeholders (Bird, Hall, Momente \& Reggiani, 2007).

CSR has recurrently been challenged by hard-line advocates of capitalism (Nehme \& Wee, 2008), and neoclassical economists, postulating that organizations should be solely focused on maximizing the company's long-term market value, specifically, the wealth of the shareholders (Bird et al., 2007). In line with this, many detractors of CSR fall back on the Friedman's (1970) thesis of organizations existing purely for the maximization of shareholder wealth, and that directors of organizations are not authorized to practise philanthropy with owner's wealth. Friedman (1970) further argues that organizations are artificial entities that cannot possess social responsibilities, and if organizations were to engage in social duties, these would be difficult to define. Davis (1973) built upon Friedman's stance, postulating that skills in organizations are focused towards finance and operations, and are, therefore, not equipped to engage in socially-orientated decisionmaking activities. Thus, in organizations where skills are focused on CSR initiatives, the risk is that these organizations could fail to meet their primary business objectives, putting the organization at a competitive disadvantage (Aupperle, Carroll \& Hatfield, 1985). However, in the wake of the 2008 global economic crisis, business organizations are attempting to redefine their purpose, which poses new questions and challenges in terms of what an organization must do and how it must go about doing it (Goldman, Nienaber \& Pretorius, 2015).

Multinational operations have added a further dimension to CSR, as it is also viewed as a mode of governance which can overcome abating labor legislation confined to national boundaries (Bethoux, Didry \& Mias, 2007). In emerging economies, the presence of multinational organizations is viewed as having a positive effect on working conditions as these multinationals are viewed as agents of change, bringing about not only financial and economic benefits, but also contributing to ethical standards in business (Chiara \& Spena, 2011; Bethoux, et al., 2007).

\subsection{Corporate social responsibility in multina-} tional organizations. Multinational organizations have formal CSR functions or program in place governed by policies specific to home country requirements (Baines, 2009; Galbreath, 2006). However, the context of CSR can vary considerably between countries where multinational organizations operate, reflecting the distinctive traits of host countries. Multinational organizations may have set CSR policies in the home country, but host country differences must be considered when implementing
CSR in a global context (Galbreath, 2006), with the nett result that global CSR policies often involve customized initiatives in host countries influenced by institutional and social pressures specific to these host countries. These pressures can emanate from cultural norms and values, the regulatory environment of the host country and the expectations of NGO's (Chiara \& Spena, 2011; Hinson \& Ndlovu, 2011).

Often, a global CSR strategy in a multinational organization is not adopted by particular subsidiaries or host countries (Galbreath, 2006), which implies heightened challenges for multinational organizations (Hinson \& Ndlovu, 2011). Global standards and codes, such as those proposed by OECD (Organization for Economic Development) and the United Nations, have recommended various ethical and socially responsible policies which multinational organizations should adopt, could serve as minimum guidelines for multinationals to consider when implementing CSR initiatives in host countries (Baines, 2009). The OECD guidelines for multinational enterprises were set up to provide codes of conduct based on shared values for multinational organizations operating in foreign countries, ensuring that they operate in accordance with local government policies (Baines, 2009). These are voluntary standards (covering issues on human rights, labor laws, environment and bribery) which a government would recommend to a multinational organization (Adeyeye, 2011). Another driver of CSR, specific to the financial services sector, are the Equator Principles. These are also voluntary principles that detail how improvements in social and environmental initiatives are to be undertaken by financial institutions (Baines, 2009). The original principles were based on guidelines and policies instituted by the World Bank and International Finance Corporation (Adeyeye, 2011). Where these guidelines have been adopted and managed successfully, relations between multinational organizations and host countries seem to be healthy, attaining a vigorous level of reciprocity and understanding of each parties' needs (Baines, 2009).

Despite these guidelines, the World Business Council for Sustainable Development (WBCSD) argues that no universal standard for CSR is possible, as regulatory and cultural variables are far too disparate in host countries (Adeyeye, 2011). Therefore, industry-initiated codes, such as the Equator Principles, are subject to much criticism, with accusations centring around a lack of transparency with respect to the implementation of the principles.

1.2. Corporate social responsibility in emerging markets. Multinational organizations active in developing economies are, often, the primary owners 
of businesses and possess greater wealth than local communities (Hinson \& Ndhlovu, 2011). These communities are impacted by international business operations, and are increasingly placing pressure on multinational organizations to contribute towards the welfare of society (Cheng \& Ahmed, 2010). The expectation is that these multinational organizations should compensate for the poor social standing of host communities through the implementation of community upliftment and infrastructure development program (Dobers \& Halme, 2009).

Multinational organizations have come to realize the benefit and importance of doing business in emerging economies and realize that there is a requirement to display high corporate responsibility standards and that these are usually very different from what is expected in developed economies ( $\mathrm{Da}$ Piedade \& Thomas, 2006b). However, multinationals operating in emerging economies need to be cognisant of weaker governance structures than might be prevalent in developed nations (Okpara, 2011). Emerging economies are often associated with a lack of ethical norms, turbulent socioeconomic conditions and weak legal systems, which tend to affect the reputation of organizations operating in such economies (Peters et al., 2011).

Focusing on South Africa as an emerging economy, Fig (2005) argues that CSR in South Africa has been influenced by many historical events and by the belief that the business sector has contrived to perpetuate the legacy of apartheid, a sentiment echoed by Dzansi and Pretorius (2009). As economic and political power shifted in South Africa post 1994, there was a strong belief that large organizations had generated profits through human rights violations. Although the business sector did not undergo legal proceedings to rectify past wrongdoings, the African National Congress government did have an expectation that the South African business community would address past injustices, and, thus, the need to transform manifested through CSR (Fig, 2005). Baskin (2006) argues that, due to South Africa's history, two distinct CSR practices have become apparent in many organizations:

- contributions to education;

- high involvement in the management of HIV/AIDS.

Da Piedade and Thomas (2006a) add six critical CSR issues relevant to South African organizations, these being poverty alleviation, health care, housing, governance, land distribution and environmental conservation.

It is evident that a standard approach to CSR presents challenges for organizations active in South Africa. Apart from a moral obligation to ad- dress past injustices, they are also subject to transformation, aimed at obliging companies to take active steps in addressing the representation of black people (and women) in management, as well as equity ownership, and in procurement (Baskin, 2006). The Broad Based Black Economic Empowerment (BBBEE) charter, developed jointly by government and business, stipulates targets for change with respect to increased employment of black people, ownership, promotion and training, and procurement of goods and services from black people (Fig, 2005). The key elements covered in the BBBEE regulatory framework are employment equity, skills development and ownership, and corporate social responsibility (referred to in the BBBEE charter as Corporate Social Investment CSI) (Skinner \& Mersham, 2008). Incorporating CSI into the BBBEE scorecard has led to an increase in business involvement and contribution towards community development (Hinson \& Ndhlovu, 2011).

Incorporating CSR in South Africa's legal system may inherently create a problem in that there could be a tendency by organizations to only respond to the legal requirements, thus, reducing social responsibility to mere compliance and not a principle issue. However, Hinson and Ndhlovu (2011) refer to instances where a number of organizations (such as Old Mutual and Nedbank) have gone beyond the call of duty and have won international awards in excellence for their contributions towards CSR.

\section{The research setting}

As mentioned, the setting for this research is a bank that, before 2005, was one of the biggest commercial South African banks. In 2005, a UK based multinational bank (referred to as the parent company) acquired a $56 \%$ holding in this bank. Although the branding and identity of this new South African subsidiary did not change, the parent company's branding has gradually been introduced, and is set to replace the current branding. The parent company has a presence in over 50 countries, and it divides its operations into four operational regions, these being Asia Pacific (13 countries), the Americas (six countries), Europe (21 countries) and Africa and Middle East (19 countries).

\section{Rationale for conducting the research}

Literature points to the notion that multinational organizations based in developed economies appear not to have a full understanding of the CSR issues and challenges that are relevant in host country operations, especially in developing economies. In many instances, social responsibility directives are passed down by host country governments or arise from socio-economic pressures in the host country, 
which is often vastly different from the CSR expectations that have been set out by the parent company. Therefore, literature seems to suggest that the CSR expectations and practices of a parent company can be at odds with those of its host country subsidiaries.

Resultant from the problem outlined above, this study will address the following research question:

Is there an evident gap in CSR expectations and practices between a multinational bank and its South African subsidiary?

To answer this research question, the aim of this study is to explore the CSR expectations and practices of a multinational bank, its South African subsidiary in an effort to assess whether a gap exists in terms of these expectations and practices, and if a gap is evident to gain an understanding of the extent and nature of this gap.

\section{Research methodology}

As this study wishes to explore the CSR expectations of a multinational bank and its South African subsidiary, the study was conducted from an interpretive point of view employing qualitative research methods. As the research is dependent upon the understanding and experiences of role players within the chosen research setting, an interpretive paradigm was deemed appropriate (Strauss \& Corbin, 1990). Due to the fact that a specific setting was researched, an in-depth understanding of this context was sought to shed light on the research question. Qualitative methods were deemed appropriate for gaining such a level of understanding (Towers \& Chen, 2008; Strauss \& Corbin, 1990). Furthermore, a qualitative case study design was employed, as case studies focus on understanding the dynamics present within a single, identifiable setting (Eisenhardt, cited in Naslund, 2002; Denscombe, 2007).

A judgemental sampling strategy was followed, ensuring that the research only solicited data from research subjects that could contribute meaningfully to the research (Henning, van Rensburg \& Smit, 2004; Neuman, 2011). The research population consisted of social responsibility practitioners of the bank the study was conducted in, termed Community Investment Specialists by this bank. The sampling process was aided by the Corporate Citizenship General Manager for Africa of the bank, stationed in Johannesburg, who helped to identify suitable research participants, and who was helpful in providing context into the CSR landscape of both the parent company and its South African subsidiary. Ten research participants were selected from the parent company's head office in London and offices across Africa. All research participants had high-level CSR experience, including CSR strategy formulation, execution and reporting, and all had insight into CSR operations and initiatives in South Africa.

Data were collected through either semi-structured personal interviews or through solicited essays, depending on the access to the research participant. Interviews were guided by an interview schedule informed by literature. The same interview schedule served as point of departure for a briefing document sent to those research participants who agreed to form part of the study, but who could not be met in person for an interview, generally, those research participants based in London and those based in other African countries. This briefing document requested participants to provide an essay on the issues contained therein.

Complementary to the data solicited from the research participants, document dealing with the banks CSR on a global and local level were also analyzed. These included the bank's annual report (specifically, the sustainability review section), CSR policy and strategy documents, CSR high level program documents, citizenship communication plans, and its corporate citizenship intranet site.

Gathered data were subject to a variation of Grounded Theory as a method of analysis as opposed to research design, as it allowed for the reality pertaining to CSR expectations and initiatives of the parent company and subsidiary of the bank to emerge from the gathered data. The process of Grounded Theory analysis proposed by Strauss and Corbin (1990) was used in this study, which involves assigning the initial data to a few tentative categories and continually adding new data to them, at the same time, interrogating whether the new data fit the parameters of the established categories or whether new categories need to be added (Kendall, 1999). The analytical process involved three rounds of coding. During open coding, sentences were allocated labels, and every similar meaning phrase received the same label while every 'new' meaning phrase was allocated a new label, resulting in a series of emerging themes (Babbie \& Mouton, 2004; Henning et al., 2004). During axial coding, relations and linkages among these themes were revealed, while selective coding enabled the construction of an essential 'narrative' of the entire dataset as it pertained to the CSR expectations and praxis in the bank, both on a global and subsidiary level.

Consent was obtained from the bank to perform the research, on the proviso that the name of the bank (both the parent company and the South African subsidiary) is not used in the study. The bank also requested assurance that the researcher would make 
participants aware of the study and what it involved. The researcher informed all participants that data would be treated confidentially and that participants had the right to opt out of the study at any time if they wanted to.

\section{Research findings and discussion}

Research participants collectively had 80 years of CSR experience in the bank, ranging from 3 to 15 years. All have tertiary education, with the majority having in-house community development/CSR training. This level of expertise and wealth of experience strengthens the credibility of the claims presented. Open coding resulted in 56 categories emerging from the data. Iterative rounds of axial and selective coding reduced this to 18 categories and saw the emergence of five themes permeating through all of the identified categories. These will now be discussed in turn. In the interests of brevity, a small number of supporting annotations have been included, but more evidence is available upon request from the authors.

5.1. Theme 1: the meaning of CSR. The parent company defines CSR as a pillar of a broader function which is termed citizenship. Participants understand the bank's citizenship definition, but indicate that the definition of citizenship is not obvious to all employees and stakeholders of the bank, and, thus, the terms CSR, CSI and citizenship are used interchangeably. This citizenship function seems to be passionately pursued and is focused on economic and social development of communities through sharing resources, expertise, and time.

The following interview excerpts support the claims presented above:

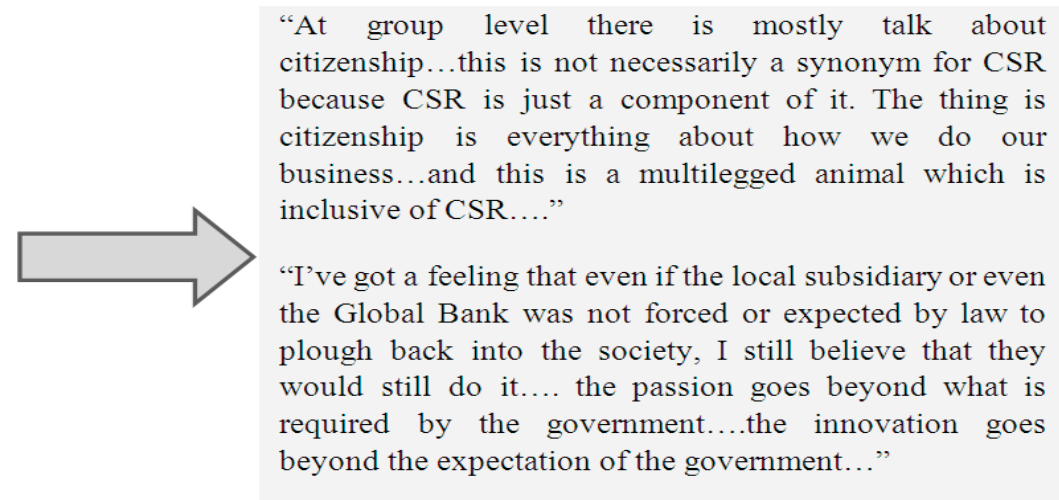

5.2. Theme 2: the bank's CSR in the home country. A global community investment team is based between the United States and the United Kingdom, and is responsible for the formulation and implementation of the parent company's global CSR strategy. This strategy is disseminated to each of the banks' five regions, where local initiatives are developed with cognizance of the global strategy. The citizenship drive of the parent company is one of its four key priorities. Participants noted that meetings, workshops and conferences take place within and between the bank's global community investment teams, thus, ensuring a constant flow of information.

The global CSR strategy implemented by the bank's subsidiaries is driven by globally developed CSR program. Respondents noted that the parent company's key theme in the CSR strategy is skills development. The global strategy is focused on the next generation, equipping them with skills to compete or be active in the global economy. Participants also mentioned that global CSR program have been designed to support the skills development theme. The bank's global CSR program was introduced to all the regions worldwide. Alignment to the skill development theme is essential in the implementation of CSR program and the bank had to exit a number of existing charities which were not aligned to the new strategy. Participants reflected that, in South Africa, enterprise skills appear to be the preferred pillar, as there is a big focus on business start-up and income generation. Global CSR strategy and program are relevant in supporting communities, but there is a sentiment that Africa's CSR needs are different in comparison to CSR needs in the UK and US, where the core pillar seems to be financial skills.

Participants noted that codes, standards and indexes, as well as factors such as business strategy and business priority issues, are vital input to the CSR strategy development. Citizenship responsibilities within the parent company require that sustainability reporting be undertaken, and the parent company needs to demonstrate commitment towards transparency and accountability regarding its economic, environmental, social, and governance performance. How the bank contributes to society from a socio-economic perspective, is an essential part of its global sustainability reporting. As the parent company is listed on the London Stock Exchange, sustainability reporting is required as part of the annual reporting process, and participants noted that the subsidiaries in developed economies are, par- 
ticularly, concerned with the FSTE for Good Index (London Stock Exchange) and the Dow Jones Sustainability Index (New York Stock Exchange). Furthermore, participants noted that the bank has to provide feedback on its CSR initiatives to the LGB (London Benchmarking Group), and that the parent company's sustainability reporting is submitted for the Dow Jones Sustainability Index and the BICCR (Business in the Community's Corporate Responsibility) Index in the US and the UK.

The following interview extracts support the claims presented:

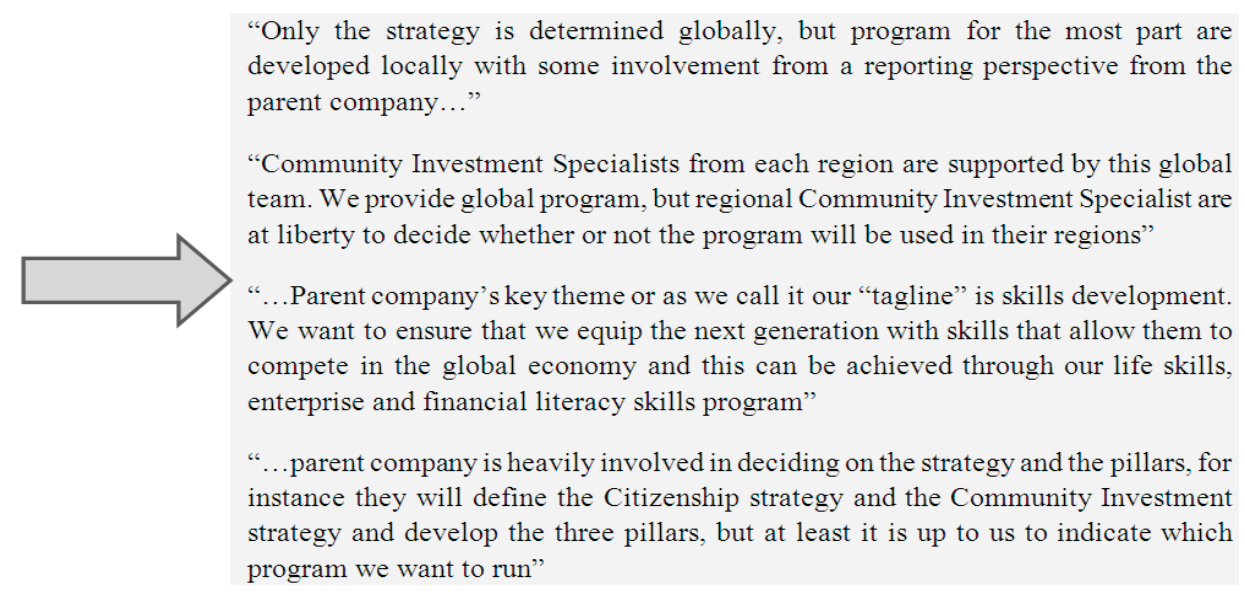

\subsection{Theme 3: CSR in the host country subsi-} diary. All participants indicated that the bank has a defined, detailed and documented global CSR strategy compiled with cognizance of inputs received from its subsidiaries. Although it is a central strategy, it is interpreted and implemented at subsidiary level bearing in mind the specific demands and challenges faced. Local CSR program is developed and approved at the discretion of the local subsidiary. Global program is not enforced at subsidiary level, but serves as guidelines to keep CSR activities aligned to global strategy. They mentioned that specific inputs do not always filter through to the global strategy, which is seen as a shortcoming. Participants evidenced a full understanding of the core focus of the global CSR strategy, which is to enable the next generation (people between 10 and 35) to achieve financial stability and independence through skills development based on three pillars, namely, life skills, enterprise skills and financial skills.

Financial skills aim to ensure that the bank focuses on increasing people's economic independence and financial security. Enterprise skills focus on creating opportunities for young people to start-up businesses or acquire business skills. Life skills target people from challenged communities, equipping them with basic personal skills necessary to grow into wellrounded individuals who can contribute positively to society. Sentiment was mixed as to which of these pillars takes precedence in the South African subsidiary. Some participants believe that the pillars are evenly prioritized, whilst others believe that enterprise skills enjoy priority as they can address the pressing issue of unemployment. Several participants felt that financial skills were the pillar the parent company was most active in, as it embraced a core skill of the bank and its service offering. At subsidiary level, CSR spend is influenced by government expectations, as South Africa has a legal requirement that $1 \%$ of Net Profit After Tax should be allocated to community upliftment, as stipulated by the Department of Trade and Industry (DTI).

In terms of assessing whether the banks' CSR strategy is effective in meeting its objectives, evidence suggests that the bank is monitoring and evaluating CSR program performance. Although the bank seems to have no set criteria for measuring the success of a CSR program, measures such as scorecard audits and post-implementation impact assessments were mentioned. Measuring tools are not applied consistently across the bank, but the monitoring of program is conducted with greater stringency by bodies such as internal auditors and the DTI, amongst others. The ability to address pertinent problems faced by communities in which the bank operates is essential when developing CSR program, and the CSR program implemented by the bank seems to be relevant to the socio-economic issues faced by local communities. The global CSR strategy brought about challenges for Community Investment Specialists in the South African subsidiary, as the new strategy meant that existing CSR program needed to be reprioritized and some had to be cut.

The majority of participants indicated that the global CSR strategy and related home country program were relevant to South African issues. Participants listed unemployment and youth population growth as pertinent issues in South Africa, and they all felt that the bank's three-pillar CSR strategy aligns to these issues. In principle, therefore, the parent company's global CSR strategy is relevant to local issues, although, it does not necessarily address priority is- 
sues such as health, shelter, hunger and basic survival in the South African context.
The following annotations serve to support the claims presented above:

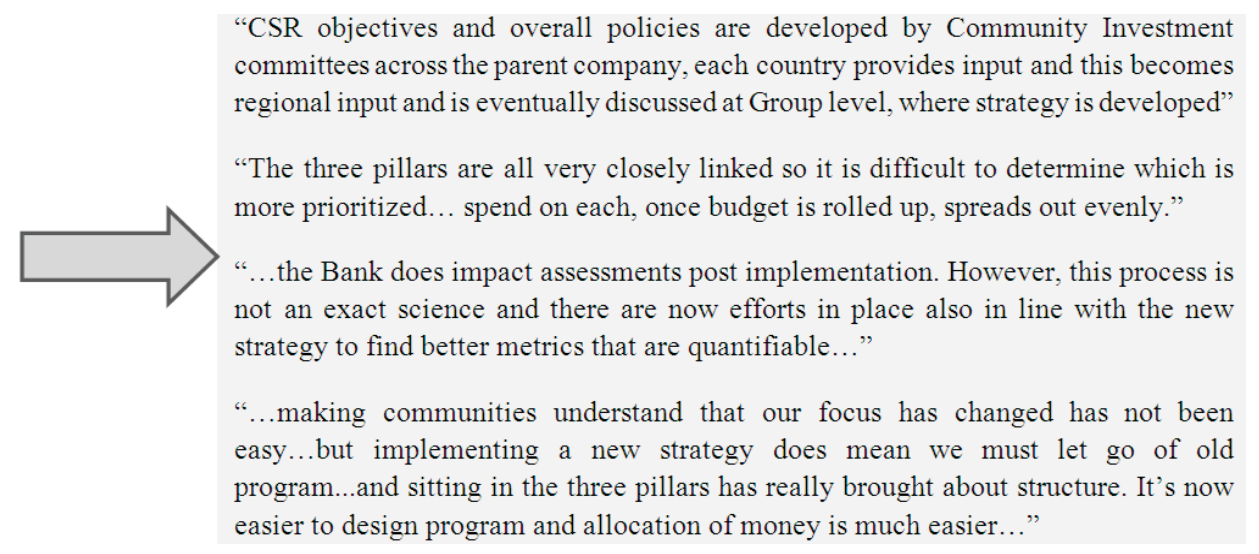

5.4. Theme 4: the role of CSR guidelines, codes and standards. Guidelines, codes and standards, whether optional or mandatory, tend to influence the CSR behavior organizations will adapt. Evidence from the interviews conducted suggests that the bank has considered the various codes, standards and guidelines (related to CSR) which impact its operations in the home and host countries alike. Although not seen as drivers of CSR program, these guidelines have an influence on CSR strategy and program development.

Whether mandatory or not, the bank makes every effort to comply with best practice in the environment in which it operates. The bank has considered various consequences that may result from noncomplience, such as negative publicity resulting from poor DTI and FSC scorecard ratings, which are made public in South Africa. Recent negative publicity on poor scorecard figures for the South African subsidiary is believed to be attributed to the parent company not assisting in improving BBBEE scorecard results.
The citizenship function of the parent company also entails sustainability reporting, demonstrating a commitment toward economic, environmental, social and corporate governance issues. Community Investment Specialists contribute to the bank's sustainability reporting. In the South Africa subsidiary, Community Investment Specialists noted that the Johannesburg Stock Exchange's Socially Responsible Investment (SRI) index plays a key role in sustainability reporting.

CSR spend seemed to be an important indicator to participants, as this is indicative of CSR activity per sector of the economy. Banks have a reputation for being highly active in the South African economy in terms of CSR contributions. All participants stated that the South African mining sector is perceived to have the highest CSR spend, closely followed by the financial services sector. Some participants believe that the mining spend is automatically greater based on higher profits generated, whereas the financial services sector appears to contribute a disproportionately large amount of CSR spend relative to market share in the economy.

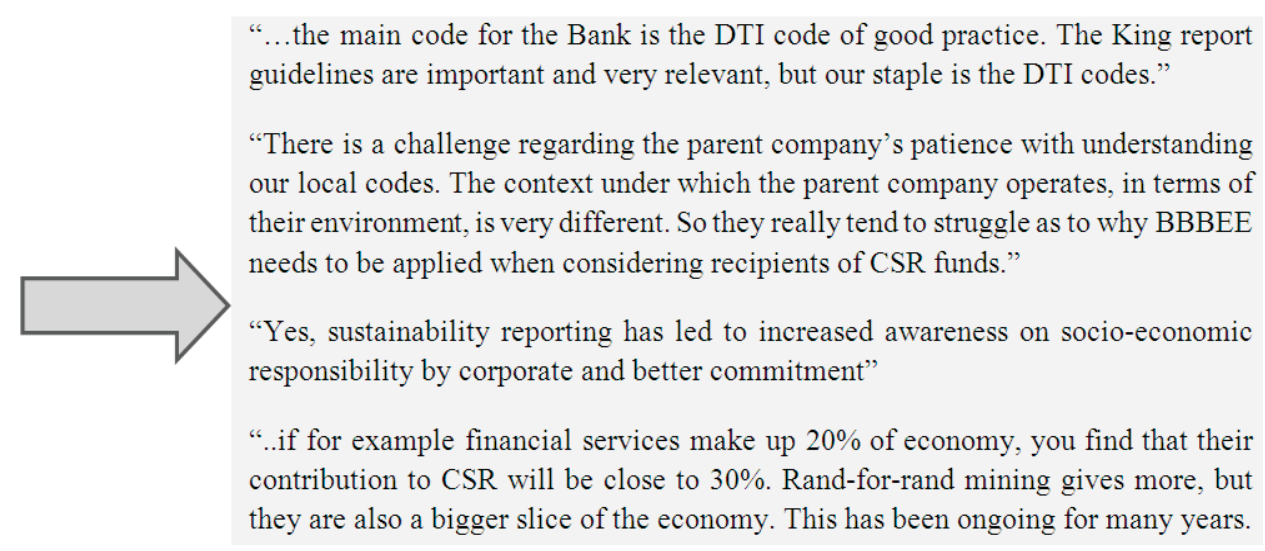

5.5. Theme 5: the effect of association with the parent company. Participants felt that being part of a multinational company has yielded positive contributions for local subsidiaries. They comment that the association with a global entity has led to growth in expertise and knowledge for the local subsidiary, CSR partners and beneficiaries. The centralized CSR function allows African countries to tap into resources available in other subsidiaries of the parent company. Furthermore, the rigorous 
monitoring and evaluation of CSR program ensures that high-powered CSR initiatives are undertaken.

The CSR professionals interviewed indicated that there can be a number of negative implications that accompany association with a multinational parent company, most importantly, that the parent company does not understand the complexities of engaging in CSR activities in South Africa. Developed nations tend to perform CSR as an added function and not as core to the organization. In South Africa, the social, political and economic history of the country has put CSR at the forefront in all organizations, as evidenced in legislation. Some participants felt that a global and streamlined approach to CSR stifles creativity. As CSR program may not fall outside the parameters of the global strategy, participants feel that they are unable to respond innovatively to critical social needs of the communities. Despite the parent company's view that the global strategy is relevant to the issues faced in its host countries, community leaders do not always agree, resulting in negative sentiments toward the efforts of the local subsidiary.

The following quotes support the claims presented above:

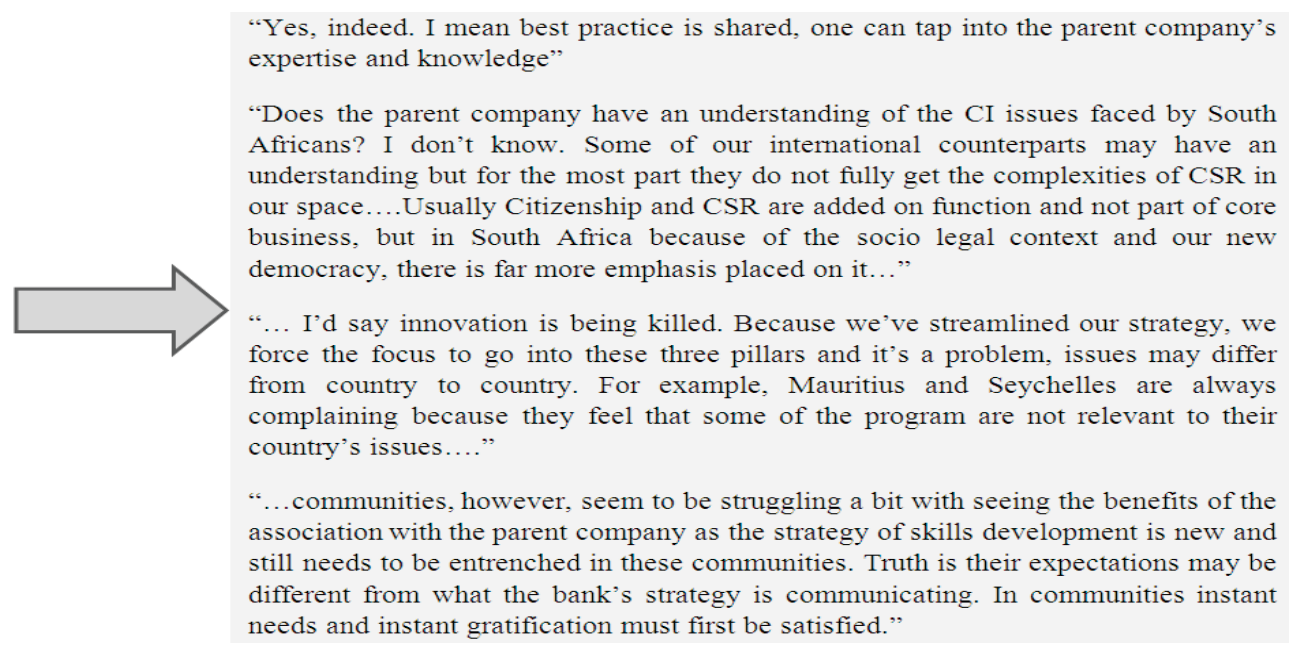

\section{Discussion and eminent conclusions}

The evidence suggests that the South African subsidiary shares a similar view on what CSR is with the slight exception of the parent company's emphasis on the broader concept of citizenship and its use of CSR implementation to broaden the parent company's global footprint. Participants believe that communities are the focal point of CSR, and when the parent company considers social investment, the focus must be on communities. Stakeholder impact is a key theme throughout the study, as participants feel that the parent company cannot grow or make decisions without the considering impact on communities. This sentiment is echoed by Bird et al. (2007), who pronounce that organizations have an obligation to determine the impact their business activities have on surrounding communities. Another conception shared by the parent company and the South African subsidiary is recognition of the need for socio-economic transformation in host countries. The Global Bank strives to uplift the lives of the people in surrounding communities through committing its resources to various initiatives. This outcome supports Da Piedade and Thomas (2006a) who state that direct investment into communities' well-being has not always been a business's responsibility, but it has become apparent that both the corporates and the communities reap the benefits.
Findings document a clear picture of how CSR strategy was formulated and rolled out throughout the parent company and its subsidiaries. It is also evident that CSR implementation is dependent on a clear and definitive CSR strategy. Findings suggest that CSR strategy formulation has a bottom-up element to it, as feedback from subsidiaries is collated and considered when devising the global CSR strategy. CSR strategy implementation has a top-down approach, as the developed CSR strategy was rolled out from head office to all subsidiaries. This supports the view of Hinson and Ndlovu (2011), who argue that globalization introduces new challenges as multiple country-specific policies need to be taken into consideration when developing CSR strategies. Furthermore, not everyone was satisfied with the CSR strategy, as not all inputs were reflected in it. Thus, subsidiary specific initiatives were developed within the parameters of the global strategy to address host country specific issues. This seems to support the view of Galbreath (2006) that centrally developed CSR strategy within a multinational organization will often be adopted and customized by its subsidiaries. The global CSR strategy, thus, serves as a guideline for the parameters in which CSR will be practised.

Central to participants' views of CSR praxis in the bank was the objective of the central CSR strategy, 
namely, skills development and its three pillars of life skills, enterprise skills and life skills. Findings indicate that all CSR activities undertaken must be aligned to this overall objective. Thus, all CSR program falls within the parameters of the three-pillar skills development framework. It seems as though this objective and the central CSR strategy have been well communicated across the bank and its subsidiaries. However, ambiguousness around how to dedicate time and resources towards the guiding principles of the framework has led to confusion and may, ultimately, impact successful implementation of CSR strategy for the African region.

Findings suggest that a central CSR strategy benefits the roll-out of CSR initiatives at subsidiary lev$\mathrm{el}$, as it is easier to roll out "ready-made" CSR program as resources, from a time and manpower perspective, are not always available to design countryspecific program. These sentiments are echoed by Skinner and Mersham (2008), who detail thirteen key elements evident across centrally planned CSR program, including alignment to core business, sharing of lessons and insights, replication of successful program, regular monitoring and measurement, and employee involvement.

Reflecting on both the central and local CSR program implemented in South Africa, participants indicated that the program addresses key issues faced by South African society such as unemployment and skills development. However, in as much as the program are deemed relevant, findings suggest that critical societal needs are not being directly addressed. These include hunger, shelter, clothing, clean water, sanitation and health. Although this is in line with Da Piedade and Thomas' (2006a) argument that issues such as health care, land distribution and housing, and poverty alleviation may not be business's responsibility, it serves to show that pressure is mounting for business to start championing these issues.

From the findings, it is evident that the parent company and South African subsidiary are aware of the global standards, codes and guidelines which may impact its CSR agenda. This is consistent with Baines' (2009) notion of supporting the use or adoption of these principles for international organizations that attempt to adopt global CSR strategies successfully. As country specific standards were evident in South Africa, the recognition and adoption of these in local CSR initiatives is consistent with Adeyeye (2011) and the World Business Council for Sustainable Development (2012), who state that CSR is dependent on legal, government and cultural issues which are all unique to a specific country and, as a result, global standards alone may not hold true. It is also evident that sustainability reporting requirements have increased the banks commitment towards CSR, in line with Sonnenberg and Hamann's (2006) argument that sustainability reporting is a key driver for measuring and motivating corporate citizenship. However, Marx and van Dyk (2011) point out that sustainability reporting may be integral to socio-economic improvements, but it is not a statutory or regulatory requirement and, therefore, only provides guidelines.

\section{Recommendations forthcoming from the study}

The financial services sector in South Africa is highly regulated and, as a result, international mergers are rare and tightly supervised. Little contextualized theory exists on how global organizations, specifically, financial services, implement CSR in emerging markets in Africa. Contextualized literature should be encouraged in an effort to allow for more informed conclusions, and deepened generalizations to be made regarding the implementation of CSR strategies in the South African context.

The findings indicate that the South African subsidiary views the current CSR strategy as relevant, but issues addressed by this strategy are not viewed as priority or considered urgent. The parent company may need to explore the concerns raised in its emerging market subsidiaries to determine where improvements can be made to current strategy, to facilitate buy-in from local communities as to the benefits of these CSR initiatives. This begs the need for greater flexibility in terms of customising local CSR strategies and initiatives. The study also highlights a serious conceptual flaw, in that CSR initiatives are not dictated to be local conditions and needs, but rather by the central CSR strategy of the parent company. Whatever the most pertinent issues faced by a given society, that is what the CSR strategy should be focused on in that locality.

\section{Limitations and avenues for further research}

The study is limited to the financial sector of the South African economy and, as a result, is not a true reflection of international organization s' CSR implementation and overall CSR activity within Africa, but rather the study looks at the link and influence of the parent company on the South African subsidiary with respect to CSR expectations and praxis. Also, the abundance of literature on CSR results in many different terminologies that are used interchangeably to define CSR. A specific limitation to this study was the use of the term CSI by the local South African Subsidiary Bank when discussing CSR as opposed to the Global Bank's use of the term Corporate Citizenship when discussing CSR. These interconnected concepts increased the degree of difficulty when demarcating the study.

A larger sample of countries and industries could be indicative of CSR praxis in emerging markets across different continents, which could enrich the little literature that currently exists on the implementation of global CSR strategies in the emerging world. See- 
mingly, multinational organizations will continue applying global standards and guidelines when pursuing CSR in host countries. However, more research is required in determining the impact of these strategies, especially in highly regulated emerging market economies.

\section{References}

1. Adeyeye, A. (2011). Universal standards in CSR: are we prepared? Corporate Governance, 11 (1), pp. 107-119.

2. Aupperle, G., Carroll, A. and Hatfield, J. (1985). An empirical examination of the relationship between corporate social responsibility and profitability, Academy of Management Journal, 22 (1), pp. 501-515.

3. Babbie, E. and Mouton, J. (2004). The practice of social research. Cape Town: Oxford University Press.

4. Baines, T. (2009). Integration of corporate social responsibility through international voluntary initiatives, Indiana Journal of Global Legal Studies, 16 (1), pp. 223-248.

5. Baskin, J. (2006). Corporate responsibility in emerging markets, Journal of Corporate Citizenship, 24 (1), pp. 29-47.

6. Bethoux, E., Didry, C. and Mias, A. (2007). What codes of conduct tell us: corporate social responsibility and the nature of the multinational corporation? Corporate Governance: An International Review, 15 (1), pp. 77-90.

7. Bird, R., Hall, A.D., Momente, F. and Reggiani, F. (2007). What corporate social responsibility activities are valued by the market? Journal of Business Ethics, 76 (1), pp. 189-206.

8. Carroll, A.B. and Shabana, K.M. (2010). The business case for corporate responsibility: a review of concepts, research and practice, International Journal of Management Reviews, 12 (1), pp. 85-104.

9. Cheng, W.L. and Ahmed, J. (2010). Incorporating stakeholder approach in corporate social responsibility (CSR): a case study at multinational corporations (MNC) in Penang, Social Responsibility Journal, 6 (4), pp. 593-610.

10. Chiara, A.D. and Spena, T.R. (2011). CSR strategy in multinational firms: focus on human resources, suppliers and community, Journal of Global Responsibility, 2 (1), pp. 60-74.

11. Da Piedade, L. \& Thomas, A. (2006). The case for corporate responsibility: arguments from the literature, $S A$ Journal of Human Resource Management, 4 (2), pp. 57-64.

12. Davis, K. (1973). The case for and against business assumption of social responsibilities, Academy of Management Executive, 8 (1), pp. 7-28.

13. Denscombe, M. (2007). The good research guide: for small-scale social research projects. New York: McGraw-Hill.

14. Dobers, P. and Halme, M. (2009). Corporate social responsibility and developing countries, Corporate Social Responsibility and Environmental Management, 16 (1), pp. 237-249.

15. Dzansi, D.Y. and Pretorius, M. (2009). The development and structural confirmation of an instrument for measuring the social responsibility of small and micro business in the African context, Social Responsibility Journal, 5 (4), pp. 450-463.

16. Ernst \& Young. (2012). Building bridges: 2012 Africa attractiveness survey. Available at: http://www.ey.com/ZA/en/Issues/Business-environment/2012-Africa-attractiveness-survey (accessed: 8 August 2013).

17. Fig, D. (2005). Manufacturing amnesia: corporate social responsibility in South Africa, International Affairs, 8 (3), pp. 509-617.

18. Freeman, E.R. (1984). Strategic management: A stakeholder approach. Boston: Pitman.

19. Friedman, M. (1970). The social responsibility of business is to increase its profits, The New York Times Magazine, 13/09, pp. 137-141.

20. Galbreath, J. (2006). Corporate social responsibility strategy: strategic options, global considerations, Corporate Governance, 6 (2), pp. 175-187.

21. Goldman, G.A., Nienaber, H. and Pretorius, M. (2015). The essence of the contemporary business organization: A critical reflection, Journal of global business and technology, 12 (2), pp. 1-13.

22. Henning, E., van Rensburg, W. \& Smit, B. (2004). Finding your way in qualitative research. Pretoria: Van Schaik.

23. Hinson, R.E. and Ndhlovu, T.P. (2011). Conceptualising corporate social responsibility and corporate social investment: the South African context, Social Responsibility Journal, 7 (3), pp. 332-346.

24. Kendall, J. (1999). Axial coding and the Grounded Theory controversy, Western Journal of Nursing Research, 21 (6), pp. 743-757.

25. Kolk, A. and Lenfant, F. (2010). MNC Reporting on CSR and conflict in Central Africa, Journal of Business Ethics, 93 (2), pp. 241-255.

26. Lund-Thompson, P. (2005). Corporate accountability in South Africa: the role of community mobilizing in environmental governance, International Affairs, 81 (3), pp. 619-633.

27. Marx, B. and van Dyk, V. (2011). Sustainability reporting and assurance practices in South Africa, Meditari Accountancy Research, 19 (1), pp. 39-55.

28. Naslund, D. (2002). Logistics needs qualitative research, especially action research, Journal of Physical Distribution and Logistics Management, 32 (5), pp. 321-338.

29. Nehme, M. and Wee, C.K.G. (2008). Tracing the historical development of corporate social responsibility and corporate social reporting, James Cook University Law Review, 15 (1), pp. 129-168.

30. Neuman, W.L. (2011). Social research methods: qualitative and quantitative approaches. Boston: Pearson. 
31. Okpara, J.O. (2011). Corporate governance in a developing economy: barriers, issues and implications for firms, Corporate Governance, 11 (2), pp. 184-199.

32. Peters, S., Miller, M. and Kusyk, S. (2011). How relevant is corporate governance and corporate social responsibility in emerging markets? Corporate Governance, 11 (4), pp. 429-445.

33. Sharma, A.K. and Talwar, B. (2005). Insights from practicing corporate social responsibility: modern vis-à-vis Vedic approach, Measuring Business Excellence, 9 (1), pp. 33-45.

34. Skinner, C. and Mersham, G. (2008). Corporate social responsibility in South Africa: emerging trends, Society and Business Review, 3 (3), pp. 239-255.

35. Sonnenberg, D. and Hamann, R. (2006). The JSE socially responsible investment index and the state of sustainability reporting in South Africa, Development Southern Africa, 23 (2), pp. 305-320.

36. Strauss, A. and Corbin, J. (1990). Basics of Qualitative Research. Newbury Park: Sage.

37. Tobey, D.H. and Perera, B.Y. (2012). Corporate social responsibility initiatives: a stakeholder model for aligning competing values in West Africa, African Journal of Economic and Management Studies, 3 (1), pp. 95-115.

38. Towers, N. and Chen, R. (2008). Employing the participative paradigm as a valid empirical approach to gaining a greater understanding of contemporary supply chain and distribution management issues, International Journal of Retail \& Distribution Management, 36 (8), pp. 627-637.

39. Vurro, C. and Perrini, F. (2011). Making the most of corporate social responsibility reporting: disclosure structure and its impact on performance, Corporate Governance, 11 (4), pp. 459-474.

40. World Business Council for Sustainable Development (2012). Overview. Available at: http://www.wbcsd.org/ about.aspx (accessed 26 May 2012). 